\title{
Factor Analysis of Service Performance in Higher Education Institutions
}

\author{
Endah Sundaning Kinanti \\ Faculty of Economics and Business \\ Universitas Padjadjaran \\ Hamzah Ritchi \\ Faculty of Economics and Business \\ Universitas Padjadjaran \\ Sofik Handoyo \\ Faculty of Economics and Business \\ Universitas Padjadjaran
}

\begin{abstract}
This research aims to examine the determinants of service performance in higher education institutions on student perceptions. This research uses Exploratory Factor Analysis (EFA) in determining the factors. The construct was built based on the literature on service performance and higher education institutions. Data were collected using a questionnaire to a state university with legal entity students in Bandung. The results indicated that there are seven determinants of service performance, namely reliability, assurance, tangibles, responsiveness, access, and reputation. The total variance of these factors is 65.7 percent, which means that the seven factors determine $65.7 \%$ of service performance in higher education in Indonesia, and 34.3\% is defined by other factors that are not examined in this research. The results of this study contribute to the literature on service performance factors in higher education in Indonesia. The factors can be used as a reference by higher education institutions to improve service quality in all aspects
\end{abstract}

Keywords: Service Performance; Higher Education; Exploratory Factor Analysis; State University with Legal Entity

\section{Introduction}

The increasing service facilities due to technological developments have driven service providers to develop service innovations continuously. Technology and human resources are Important factors for both business and government organizations to provide services to customers or users. Service management may provide satisfactory service quality and is expected to create an organization with excellent performance. Total Quality Management (TQM) is one of the popular approaches used in practice to manage quality. Service quality is closely associated with the service performance and it is measured by assessing the experiences of customers regarding the service received (Cronin \&
Taylor, 1994). The three TQM principles which are applied in improving quality are customer focus, continuous improvement, and employee empowerment. Customer focus is the key to successfully improving service quality; hence, organizations must be aware of the elements needed by customers (Blocher et al., 2000; Dean \& Bowen, 1994; Tenner \& DeToro, 1992; Hensler and Brunell in Fandy \& Anastasia, 2003; Gaspersz, 2001). Therefore, the organization may always create continuous improvements at every level to achieve service quality.

Currently, higher education institutions are one of the public services that provide educational services to the community, especially students. According to Law No. 12 
of 2012, higher education institutions in Indonesia consist of State Universities and Private Universities. Competition in higher education institutions continues to increase, and all of these institutions offer excellent educational opportunities. In order to become the leading preference, state universities must obtain information to determine the pretension of education service users, mainly from external parties who receive benefits and services, which is referred to as stakeholders. University students are stakeholders who have a direct relationship with universities. Therefore, student satisfaction is a way to evaluate the quality of service from an institution (Amin, 2017). Student satisfaction drives state universities to be more responsive to the needs of educational services as seen from the perception of students.

In the Government Regulation of Indonesia No. 26 of 2015, the government established State Universities with a legal entity. Those universities have the autonomy to manage their institution as a center for the implementation of Tridharma (three functions of higher education institutions). With the establishment of State University with legal entity as well as educational autonomy, state universities can manage the entire aspects of academic and non-academic itself. It renders state universities to provide students with service innovation and compete with customeroriented private universities. In total, there are 11 State University with Legal Entity in Indonesia. There are five State University with Legal Entity located in West Java Province, and three of them located in Bandung City with predicate good quality universities ( Cluster 1). It refers to Institut Teknologi Bandung (ITB), Universitas Padjadjaran (UNPAD), and Universitas Pendidikan Indonesia (UPI). The study was intended to investigate the service performance factor in State University with Legal Entity in Bandung Based on the students' perceptions.

There are limited researches conducted in Indonesia regarding service performance in education institutions. Whereas countries with rapid progress in the field of education have researched about service performance. A research conducted by Abdullah (2005) has examined the factors using exploratory methods in measuring the performance of higher education institutions in Malaysia. Moreover, the explanatory study by Mwiya et al. (2017) examined the service performance model on customer satisfaction at the University of Zambia. Several researchers conducted explanatory research on service quality using the service quality model. Khodayari and Khodayari (2011) measured service quality at Islamic Azad University in Iran by identifying service quality factors using factor analysis and assessing a quality provided by universities in Iran. Chopra, Chawla \& Sharma (2014) have tested student satisfaction in management and education institutions that compared perceptions and expectations. In Indonesia, Yuniarti (2017) has examined service quality at the Faculty of Economics at Universitas Jambi.

This study was motivated by the fact that there is a lack of research conducted in Indonesia regarding service performance in educational Institutions. The study contributes in terms of enriching literature in the field of service performance in education institutions. The novelty of the study lies in the methodology used to understand service performance in educational institutions, which is referring to the Exploratory Factor Analysis (EFA). The aim is to identify the underlying dimensions used by students in their evaluation of the quality of education they receive and to determine the importance of this matter in their evaluative process.

\section{Literature Review and Hypothesis Development}

\section{Total Quality Management (TQM)}

Total Quality Management (TQM) is a technique or method in the field of management accounting as a strategy used to continuously improve the quality of performance by an organization using available resources maximally to satisfy customers (Gaspersz, 2001; Porter \& Gamble in Blocher et al., 2000; Soewarso, 2004). According to Blocher et al. (2000); Dean and Bowen (1994); Tenner and DeToro (1992); Hensler and Brunell in Fandy \& Diana (2003); Gaspersz, (2001) Total 
Quality Management (TQM) has the following basic principles: 1) Customer focus; 2) Continuous improvement; 3) Employee empowerment and involvement.

Total Quality Management (TQM) in higher education is manifested in the interaction between students as customers or parties who receive services and lecturers as well as the operational staff of higher education as those who provide the services. Total Quality Management is a way to ensure that institutions perform well, provide high-quality education, research, and related services to meet the needs of stakeholders on an ongoing basis and achieve excellence by higher education institutions (Sohail \& Shaikh, 2004; Sakthivel, Rajendran \& Raju, 2005; Elmuti, Kathawala \& Manippallil, 1996).

\section{Service Performance}

Service performance is a measuring instrument of service quality based on a performance perspective (Cronin \& Taylor, 1992). Service performance in educational services at an institution occurs when there are interactions in the provision of services to customers, namely students, in the process of providing quality performance, human resources and facilities are needed where customers can search for information when interacting with service providers and then evaluate the services provided. The principle is that customers assess the performance of the activities carried out, which in this case is understood and perceived by customers during the service delivery process (Zeithaml \& Bitner, 2000; Francis, Muzaffer, \& Vincent, 2000).

Cronin \& Taylor (1992) claimed SERVPERF as a measurement of service performance, by merely measuring service quality based on the performance. Compared to other service quality measurements such as SERVQUAL that measure the service quality by comparing the reality and customer's expectations from Parasuraman, Zeithaml \& Berry (1985). SERVPERF produces more reliable estimates, greater convergent and discriminant validity, higher explanation variance. Therefore it generates less bias than the other scales (Cronin \& Taylor, 1992;
Parasuraman, Zeithaml \& Berry, 1994; Quester, Romaniuk and Wilkinson, 2015; Llusar \& Zornoza, 2000). Cronin and Taylor (1994) developed the results of their research and produced SERVPERF as a variant of the SERVQUAL model, which adopted a performance-based approach to measure service quality by only focusing on the perception component. Cronin \& Taylor (1992) dimensions of service performance include: 1 ) Tangible; 2) Reliability; 3) Responsiveness; 4) Assurance; and 5) Empathy, which is measured using question indicators from existing dimensions.

\section{Higher Education Institution}

According to Law No. 20 of 2003 concerning the Education System, education should be conducted through formal, non-formal, and informal channels. As mentioned in Law No. 12 of 2012 that higher education institutions are higher education implementation units as an advanced level of education at the level of formal education. Higher education activities are monitored by the Ministry of Research, Technology and Higher Education of Indonesia. The Ministry has the central vision of realizing high-quality education and the ability of science, technology, and innovation to support the nation's competitiveness. Realizing continuous improvement in the quality of higher education requires commitment from the entire elements of educational institutions that provide satisfaction for its customers.

\section{Higher Education Performance}

The performance of higher education institutions in Indonesia is assessed by the Ministry of Research, Technology, and Higher Education. Assessment conducted using inputs, processes, outputs and outcomes. Result of the assessment is clustering and ranking of higher education institutions. Higher education ratings can provide images to external parties, the public, government and students. In selecting higher education institutions, external parties assess that these products are inseparable from the product characteristics, such as accreditation, quality, and infrastructure. In addition, the choice of students at higher education institutions is more about trust, its 
image, the quality of service and satisfaction upon the institutional performance (Gunarto \& Gaffar, 2016).

Research conducted by Abdullah (2005) contributes novel measurements in measuring performance in higher education institutions, called HEdPERF (Higher Education Performance). This performance-based measurement scale is becoming a novel and more comprehensive matter that attempts to capture the determinants of service quality in the higher education sector through the entire aspects of the institution. Abdullah (2005) stated that measurements using HEdPERF are seen from four dimensions, namely as follows: 1) Non-academic aspects; 2) Academic aspects; 3) Reliability; 4) Empathy.

\section{Methods}

The approach used in this research is quantitative. The analysis method used in this research is factor analysis. Statistical analysis used in this study is Exploratory Factor Analysis (EFA). Exploratory factor analysis with data reduction is used to identify structures from studies that have not been widely tested, and generally, exploratory factor analysis is used by researchers to develop the scale of measurement of a research variable (Jogiyanto, 2018). The research object studied is the dimension of service performance variables using the HEdPERF construct namely nonacademic aspects, academic aspects, reliability and empathy. The SERVPERF constructs consist of tangible dimensions, responsiveness, assurance, reliability, and empathy. The factors of service performance were assessed based on student's perception using questioner instrument. The factors were identified using data reduction (EFA) with factor loading $>0.05$ considered as a valid dimension of factor.
This research uses an exploratory factor analysis (EFA) method to classify variables based on the intercorrelation so that relationships and patterns can be understood and interpreted (Jogiyanto, 2018). Exploratory factor analysis procedures are as follows: 1) Calculate the indicator correlation matrix by the Kaiser-Meyer Olkin (KMO) method; 2) Factor extraction using the Principal Component Analysis (PCA) method; 3) Factor rotation using the Varimax method; 4) Naming Factors. The consistency and stability of instruments from the questionnaire are measured by using a reliability test.

\section{Sampling, Data Collection and Measures}

The population in this study were all students at State University with Legal Entity. The sampling technique used was purposive sampling. The criteria that must be fulfilled in the sample are 1) State University with Legal Entity in the city of Bandung; 2) State University with Legal Entity - Cluster 1;3) Faculty of Economics and Business at State University with Legal Entity in the city of Bandung; 4) bachelor, master and doctoral educational level. The data of the object to be examined are primary data, and the data collection technique is a field study, namely a questionnaire in the form of a statement addressed to respondents as users of services in each state university through an electronic questionnaire. Then, a literature study is conducted by finding relevant literature in the form of journals, books, papers, previous research. There are seven constructs proposed in this study to be examined as the service performance factor. The construct derives from relevant theories and literature. Details of the construct, theoretical basis, measurement items, and references are presented in Table 1.

Table 1. Construct Measurement

\begin{tabular}{cccc}
\hline Constructs & $\begin{array}{c}\text { Theoretical } \\
\text { Framework }\end{array}$ & $\begin{array}{c}\text { Number of } \\
\text { items } \\
\text { Measurement }\end{array}$ & Adapted from \\
\hline Tangible & SERVPERF & 5 items & $\begin{array}{c}\text { Parasuraman et al. } \\
(1985,1988,1994), \text { Cronin } \\
\text { \& Taylor (1992, 1994) }\end{array}$ \\
\hline
\end{tabular}




\begin{tabular}{|c|c|c|c|}
\hline Responsiveness & SERVPERF & 5 items & $\begin{array}{c}\text { Parasuraman et al. } \\
(1985,1988,1994), \\
\text { Cronin \& Taylor (1992, } \\
1994)\end{array}$ \\
\hline Assurance & SERVPERF & 6 items & $\begin{array}{c}\text { Parasuraman et al. } \\
(1985,1988,1994), \\
\text { Cronin \& Taylor (1992, } \\
\text { 1994) }\end{array}$ \\
\hline Academic Aspect & HEDPERF & 7 items & Abdullah (2005) \\
\hline $\begin{array}{l}\text { Non-academic } \\
\text { Aspect }\end{array}$ & HEDPERF & 6 items & Abdullah (2005) \\
\hline Empathy & $\begin{array}{l}\text { SERVPERF, } \\
\text { HEDPERF }\end{array}$ & 6 items & $\begin{array}{l}\text { Parasuraman et al. } \\
(1985,1988,1994), \\
\text { Cronin \& Taylor (1992, } \\
\text { 1994), Abdullah (2005) }\end{array}$ \\
\hline Reliability & $\begin{array}{l}\text { SERVPERF, } \\
\text { HEDPERF }\end{array}$ & 11 items & $\begin{array}{l}\text { Parasuraman et al. } \\
(1985,1988,1994), \\
\text { Cronin \& Taylor (1992, } \\
\text { 1994), Abdullah (2005) }\end{array}$ \\
\hline
\end{tabular}

Overall, there were 46 question items used to develop the questionnaire instrument. The questionnaire was designed using closed questions with a 4-point Likert scale model, where 1 refers to a highly unimportant item and 4 refers to a highly important item. Respondents were asked to assess what are the important components that must be present in education services in higher education.

\section{Results}

Sample Demographics
Questionnaires were distributed via an electronic platform to respondents, namely students on the Faculty of Economics and Business from the Institut Teknologi Bandung (ITB), Universitas Padjadjaran (UNPAD), dan Universitas Pendidikan Indonesia (UPI) on the bachelor, master, and doctoral study program. In total, 161 questionnaires were collected, but 10 questionnaires were incomplete and were therefore excluded from the data source. A total of 151 questionnaires were completed and fulfilled the requirements for further processing. Detailed information on respondents are presented in Table 2 below:

Table 2. Respondents Demographics

\begin{tabular}{lll}
\hline Demographics & Total & Percentage \% \\
\hline Institution & & \\
ITB & 30 & $20 \%$ \\
UNPAD & 80 & $53 \%$ \\
UPI & 41 & $27 \%$ \\
Age & & \\
$<22$ & 56 & $57 \%$ \\
$22-39$ & 83 & $8 \%$ \\
$20-60$ & 12 & $0 \%$ \\
$>60$ & 0 & $66 \%$ \\
Gender & & $34 \%$ \\
Male & 51 & \\
Female & 100 & \\
Level of Study & & \\
\hline
\end{tabular}




\begin{tabular}{lll}
\hline Bachelor & 61 & $40 \%$ \\
Master & 78 & $52 \%$ \\
Doctoral & 12 & $8 \%$ \\
Current study semester & 30 & $20 \%$ \\
1st Semester & 9 & $6 \%$ \\
2nd Semester & 32 & $21 \%$ \\
3rd Semester & 10 & $7 \%$ \\
4th Semester & 38 & $25 \%$ \\
5th Semester & 2 & $1 \%$ \\
6th Semester & 18 & $12 \%$ \\
7th Semester & 2 & $1 \%$ \\
8th Semester & 7 & $5 \%$ \\
9th Semester & 0 & $0 \%$ \\
10th Semester & 0 & $0 \%$ \\
11th Semester & 0 & $0 \%$ \\
12th Semester & 0 & $0 \%$ \\
13th Semester & 3 & $2 \%$ \\
14th Semester & & \\
\hline
\end{tabular}

\section{Reliability Test}

The reliability test with Cronbach' $\alpha$ with a correlation value of $>0.7$ means that the indicators in the questionnaire are reliable and are usable. The results of the reliability test showed the reliability value of the indicator. The results of the reliability are presented in Table 3 below:

Table 3. Reliability Test

\begin{tabular}{llc}
\hline Constructs & $\begin{array}{c}\text { Number of items } \\
\text { Measurement }\end{array}$ & Cronbach' $\boldsymbol{\alpha}$ \\
\hline Tangible & 5 items & 0.768 \\
Responsiveness & 5 items & 0.755 \\
Assurance & 6 items & 0.756 \\
Academic Aspect & 7 items & 0.769 \\
Non-academic Aspect & 6 items & 0.824 \\
Empathy & 6 items & 0.809 \\
Reliability & 11 items & 0.900 \\
\hline
\end{tabular}

\section{Exploratory Factor Analysis (EFA)}

Statistical techniques using EFA requires a large amount of data. Therefore, adequacy data must be tested before conducting further analysis using EFA. Kaiser-Meyer-Olkin (KMO) and Bartlett's test are terminologies in EFA that is used to measure the adequacy of sampling and measure the homogeneity of indicators as a condition of construct correlation. To conduct exploratory factor analysis, the KMO value must be greater than
0.5 and Bartlett's test must be less than 0.05 (Jogiyanto, 2018).

The information described in Table 4 is the result of the Kaiser-Meyer-Olkin (KMO) and Bartlett test. The result indicate that the KMO value is $0.850(>0.5)$ and the Bartlett test is significant $(\mathrm{p}=0,000)$. It implies that the requirements for data sufficiency for factor analysis have been fulfilled. KMO values with a value in the range of $\geq 0.80$ indicate that the adequacy of the data to conduct an Exploration Factor Analysis is meritorious. Bartlett's Test of 
Sphericity shows a significant indication ( $\mathrm{p}<$ 0.05). The KMO and Bartlett's Test results imply that the amount of data used in this study is sufficient to carry out a factor analysis.

Table 4. KMO and Bartlett's Test

\begin{tabular}{|c|c|c|}
\hline \multicolumn{2}{|c|}{ Kaiser-Meyer-Olkin Measure of Sampling Adequacy. } & \multirow{2}{*}{$\begin{array}{l}0.850 \\
2332.741\end{array}$} \\
\hline Bartlett's Test of Sphericity & Approx. Chi-Square & \\
\hline & $\mathrm{df}$ & 435 \\
\hline & Sig. & 0.000 \\
\hline
\end{tabular}

After conducting the adequacy data test, the data was extracted to discover the component pattern matrix. The Principal Component Analysis (PCA) extraction method and the Kaiser Varimax Normalization rotation method were used. The EFA results show that there are seven initial factors identified as service performance and 26 elements of factor. Before extraction, there were seven construct factors and 46 elements that were proposed as potential service performance factors. Data extraction filters out factor elements by excluding elements with factor loading values below 0.5 . Several factor elements have been found to have two or more loading factors on different factor matrices (cross-loading). Factor elements with cross-loading conditions are removed from the factor matrix. Then a factor that has less than three rotational elements is omitted from the matrix because the element can not stand alone as a factor.

Table 5. Results of Exploratory Factor Analysis
The cumulative of the variance in the factor construct is 65.7 percent. This means that $65.7 \%$ of the service performance in higher education in Indonesia is determined by seven factors and 25 elements. In addition, 34.3 percent of the other dimensions outside this study are service performance factors. The eigenvalue value is obtained from the total variance explained in the extraction process. The seven factors have an eigenvalue of $>1$ which means that these factors can explain the indicator well. Details of the factor analysis output after data extraction and factor rotation are presented in Table 5. Each factor is labeled according to the theoretical framework used. Label names are based on judgment by considering the characteristics of the elements on each factor. The contribution of each factor as an essential component of service performance in higher education institutions can be identified from the value of the variance

\begin{tabular}{lcccc}
\hline & $\begin{array}{c}\text { Factor } \\
\text { Loading }\end{array}$ & $\begin{array}{c}\text { Eigen } \\
\text { value }\end{array}$ & $\begin{array}{c}\text { Variance } \\
\text { \% }\end{array}$ & $\begin{array}{c}\text { Cumulative } \\
\text { Variance } \\
\text { \% }\end{array}$ \\
\hline $\begin{array}{l}\text { Factor 1: Reliability } \\
\text { The ability of operational staff }\end{array}$ & 0.513 & 31.8 & 12.4 & 12.4 \\
Integrated service centers & 0.763 & & & \\
Speed of service & 0.786 & & & \\
Reliability of service information & 0.865 & & & \\
Service efficiency & 0.667 & & & \\
& & 9.6 & & \\
Factor 2: Assurance & & & & \\
Operational staff skills & 0.623 & & & \\
Fulfillment of student needs & 0.758 & & & \\
Attention from the institution to students & 0.694 & & & \\
\end{tabular}




\begin{tabular}{ll}
\hline Factor 3: Tangible & \\
Institutional equipment & 0.843 \\
Institutional physical facilities & 0.840 \\
Public facilities & 0.805 \\
Campus environment & 0.638
\end{tabular}

Factor 4: Responsiveness

Teaching staff responses

5.5

0.677

Handling requests by operational staff $\quad 0.687$

Politeness of the operational staff $\quad 0.685$

Support from institution to operational $\quad 0.513$ staff

Factor 5: Academic

The attention of teaching staff $\quad 0.629$

Academic assistance from teaching staff $\quad 0.799$

Communication of teaching staff $\quad 0.668$

Responses from teaching staff $\quad 0.657$

Factor 6: Access

Student organizations

Feedback from students to institutions $\quad 0.753$

Service procedures

0.658

Factor 7: Reputation

International accreditation of study programs

Factor 1: Factor 1 consists of 5 elements based on the concept of service performance, according to Cronin and Taylor (1992). The elements of Factor 1 are the construct of assurance and reliability. Factor 1 element is dominated by the reliability construct so that Factor 1 is called reliability. The reliability factor has a variance of $12.4 \%$. It means that $12.4 \%$ of service performance factors in higher education in Indonesia is determined by the reliability of education services. Factor 1 consists of elements namely the ability of operational staff, integrated service centers, speed of service, reliability of service information, and service efficiency.

Factor 2: Factor 2 consists of 3 elements based on the concept of service performance, according to Cronin and Taylor (1992). The elements of Factor 2 are the construct of assurance and empathy. Factor 2 element contains the ability of institutions to meet the needs of students through operational staff so that Factor 2 is called assurance. The assurance factor has a variance of $9.5 \%$. It means that $9.5 \%$ of service performance factors in higher education in Indonesia is determined by the assurance of education services. Factor 2 consists of elements namely operational staff skills, the fulfillment of student needs, attention from the institution to students.

Factor 3: Factor 3 consists of 4 elements based on the service performance concept according to Cronin and Taylor (1992). The element of factor 3 is a tangible construct so that Factor 3 is called tangible. Tangible factors have a variance of $9.5 \%$. It means that $9.5 \%$ of the service performance factor in higher education in Indonesia is determined by the tangible factors from education services. Factor 3 consists of elements, namely institutional equipment, institutional physical facilities, public facilities, campus environment.

Factor 4: Factor 4 consists of 4 elements based on the concept of service performance according to Cronin and Taylor (1992). The 
elements of Factor 4 are the construct of responsiveness and assurance. The factor 4 element contains how the institution (teaching staff, operational, and bureaucracy) handles student requests so that Factor 4 is called responsiveness. The responsiveness factor has a variance of $9.2 \%$. This means that $9.2 \%$ of the service performance factor in higher education in Indonesia is determined by the responsiveness of education services.

Factor 5: Factor 5 consists of 4 elements based on the concept of higher education performance, according to Abdullah (2005).The element of Factor 5 is the academic construct so Factor 5 is called academic factors. Academic factors have a variance of $8.9 \%$. It means that $8.9 \%$ of the service performance factor in higher education in Indonesia is determined by the academic aspects of education services. Factor 5 consists of elements namely the attention of teaching staff, academic assistance from teaching staff, communication of teaching staff, responses from teaching staff.

Factor 6: Factor 6 consists of 3 elements based on the concepts of service performance and higher education performance, according to Abdullah (2005). The element of Factor 6 is the construct of reliability; the factor of Factor 6 contains the access of students in their rights and obligations to institutions so that Factor 6 is called access. The access factor has a variance of $8.5 \%$. It means that $8.5 \%$ of service performance factors in higher education in Indonesia is determined by the aspect of access to education services. Factor 6 consists of elements, namely student organizations, feedback from students to institutions, service procedures.

Factor 7: Factor 7 consists of 3 elements based on the concept of higher education performance, according to Abdullah (2005). The elements of Factor 7 are non-academic constructs containing elements about the reputation of the institution so that Factor 7 is called reputation. The reputation factor has a variance of $7.7 \%$. It means that $7.7 \%$ of the service performance factor in higher education in Indonesia is determined by the reputation of education services. Factor 7 consists of elements, namely international accreditation of study programs, international cooperation, international ranking.

Testing the service performance component in higher education using EFA produces a model of the service performance factors which can be seen in Figure 1 below

Figure 1. Model of determinants of service performance in higher education

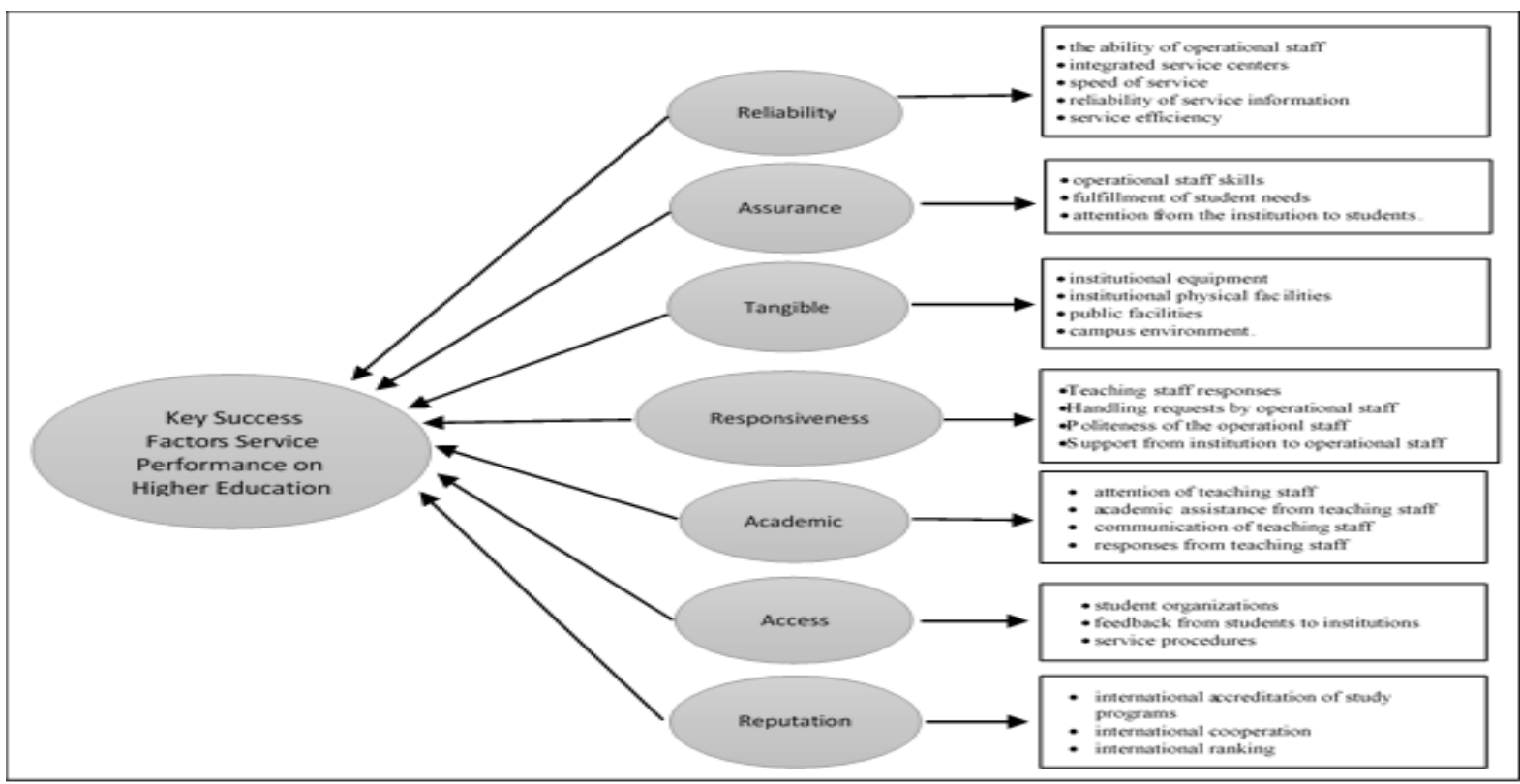




\section{Discussion}

\section{Reliability and Service Performance}

The results showed that the reliability of service is a crucial component of determining service performance. This is in line with the construct that was compiled based on previous research literature, namely Cronin \& Taylor (1992, 1994). Supported by other research, namely (Ananthanarayanan Parasuraman, Zeithaml, \& Berry, 1988; Ananthanarayanan Parasuraman et al., 1994; Anantharanthan Parasuraman et al., 1985) which stated that reliability is a dimension in determining service quality. In the higher education sector, Abdullah (2005) also claimed that reliability is a determinant of service performance. Reliability shows the ability of the service provider company to carry out the promised service reliably and accurately. The services offered are the company's promise to consumers in order to satisfy its consumers. Reliability is fulfilled when service providers satisfy the customers and deliver on their promises (Cronin \& Taylor, 1994; Ananthanarayanan Parasuraman et al., 1994; Zeithaml \& Bitner, 2000). Students believe that the services provided by institutions are capable and genuinely deliver on the promised service in a committed, honest and consistent manner (Mwiya et al., 2017). Many higher education institutions lack reliability in their services, even though students perceive reliability as an important factor in-service performance (Chopra et al., 2014).

\section{Assurance and Service Performance}

The results indicated that assurance is one of the determinants of service performance. It is in line with the construct built based on relevant literature, namely Cronin \& Taylor (1992, 1994), (Ananthanarayanan Parasuraman et al., 1988, 1994; Anantharanthan Parasuraman et al., 1985). Supported by other research, which stated that assurance is a dimension in determining service quality (Pariseau \& Mcdaniel, 1997). Assurance is needed to create and instill trust and confidence of consumers in the company (Kotler, 2001). Assurance present in the form of consumer guarantees regarding the ability, courtesy, precise product knowledge and trustworthiness of all company resources in providing services to consumer doubts (Zeithaml \& Bitner, 2000). Students consider that institutions with relevant capabilities and knowledge can gain their trust and confidence upon the service offered by the institution (Mwiya et al., 2017). Students must get assistance from the institutions as a factor of service performance (Sultan \& Wong, 2010).

\section{Tangible and Service Performance}

The results showed that tangible is one of the determinants of service performance. It is in line with the construct built based on relevant literature, namely Cronin and Taylor (1992, 1994), (Ananthanarayanan Parasuraman et al., 1988, 1994; Anantharanthan Parasuraman et al., 1985). Research by Pariseau and Mcdaniel (1997) supports that tangibility is a dimension in determining service quality. The higher (better) physical facilities of higher education can increase student satisfaction (Mwiya et al., 2017; Ali \& Mohamed, 2014). The appearance of the company's physical facilities and the state of the surrounding environment is clear evidence of the ability of services provided by the service provider company (Kotler, 2001). Direct evidence of tangibility for services can improve the quality of higher education services themselves (Amin, 2017).

\section{Responsiveness and Service Performance}

The results indicated that responsiveness is a factor of service performance. It is in line with the construct built from relevant literature namely Cronin \& Taylor (1992, 1994). (Ananthanarayanan Parasuraman et al., 1988, 1994; Anantharanthan Parasuraman et al., 1985). Responsiveness represents the speed of service, excellent and high-quality responses that may then affect consumers' points of view (Zeithaml \& Bitner, 2000; Kotler, 2001; Rigotti \& Pitt, 1992; Pariseau \& Mcdaniel, 1997). Responsiveness is provided by the entire sections in the institution, namely from lecturers, operational staff, and the bureaucracy of the higher education institution itself (Mwiya et al., 2017). Excellent service is about actualizing students' perceptions of responsiveness in offering the service (Amin, 2017). When an institution is more responsive 
to students, this may increase the satisfaction of students (Chopra, Chawla \& Sharma, 2014; Ali and Mohamed, 2014). Responsiveness was rated as an essential dimension followed by reliability, tangibility, assurance, and empathy (Chopra et al., 2014)

\section{Academic and Service Performance}

The results indicate that academics is a critical factor in-service performance. It is in line with the construct built from relevant literature, namely Abdullah (2005, 2006). Positive attitude, good communication skills, provision of consultation and feedback from lecturers to students are the critical factor in the quality of higher education service performance (Abdullah, 2005). Good academic aspects contribute to the student's satisfaction (F. Ali, Zhou, Hussain, Nair, \& Ragavan, 2016). The curriculum in higher education is a form of academic aspect as a factor of service (Sohail \& Shaikh, 2004). Japanese students are concerned about the class of each course, the experience of lecturers, research, teaching, and administration of lecturers at institutions (Sultan \& Wong, 2010).

\section{Access and Service Performance}

The results showed that access is one of the determinants of service performance (Ananthanarayanan Parasuraman et al., 1988). The findings of this research are supported by previous research from Ali et al. (2016) which stated that access is a factor of quality service. Ali also claimed that access dimension was related to ease of contact in services, ease of approaching and accessing non-academic and academic staff. Ease of access is a form of empathy (Chopra et al., 2014; Mwiya et al., 2017). (Abdullah, 2006b) developed his research on measuring service performance factors in the service environment aspect, and generated access as a factor.

\section{Reputation and Service Performance}

The results indicated that reputation is a factor of service performance. It is in line with the construct built from relevant literature namely Abdullah (2005) because the reputation element is a non-academic construct. (Abdullah, 2006b) developed his research on measuring service performance factors in the service environment aspect, and generated a reputation as a factor. Reputation shows how important the professional image of the institution is (Abdullah, 2006b). Students assume that a reputable institution can provide excellent services to obtain student loyalty ( $\mathrm{F}$. Ali et al., 2016). Reputation becomes a mediator for higher education institutions in evaluating their services for the sake of student satisfaction (Thomas, 2011).

\section{Conclusion}

The results of the study indicate that service performance at higher education institutions in Indonesia is determined by several factors. These factors are reliability, assurance, responsiveness, tangible, access, and reputation. These factors are obtained from the exploratory test using factor analysis methods. We established the constructs based on relevant literature, i.e., robust prior research. The purpose of finding the service performance factors in higher education institutions in Indonesia is to obtain a model in-service performance that can be used by higher education in Indonesia as a reference in providing services. Not only in academic terms but also in other aspects of the whole institution. The quality improvement strategy of service in higher education also aims to encounter competition from customer-focused educational institutions.

The data collection is conducted by using an electronic questionnaire to obtain the factor model. The research respondents were not comprehensive in terms of population. the sample of the study was State University with Legal Entity students in Bandung from the Faculty of Economics and Business. Due to the limited data used for analyzing, this study also has several limitations in terms of the generalization of the results. Further researches related service performance in higher education institutions can append the data collection methods by interviews with lecturers, employees, or experts in their fields. In addition, respondents can be added by minimizing the sampling criteria. 
The results of the study using exploratory factor analysis (EFA) also provide the fact that there are other important factors as the components of service performance, which are not included in this study. Future researchers can also use other relevant literature as a primary for establishing the constructs or hypotheses. Future research is also suggested to validate the results of this study using the methods with confirmatory factor analysis (CFA). This research is expected to provide an enhancement to the literature in research as well as the practice of service performance at higher education institutions, particularly in Indonesia.

\section{References}

Abdullah, F. (2005). HEdPERF versus SERVPERF: The quest for ideal measuring instrument of service quality in higher education sector. Quality Assurance in Education, 13(4), 305-328. https://doi.org/10.1108/09684880510626 584

Abdullah, F. (2006a). Measuring service quality in higher education: HEdPERF versus SERVPERF. Marketing Intelligence and Planning, 24(1), 31-47. https://doi.org/10.1108/02634500610641 543

Abdullah, F. (2006b). The development of HEdPERF: A new measuring instrument of service quality for the higher education sector. International Journal of Consumer Studies, 30(6), 569-581. https://doi.org/10.1111/j.14706431.2005.00480.x

Ali, A. Y. S., \& Mohamed, A. I. (2014). Service Quality Provided by Higher Education Institutions in Somalia and Its Impact on Student Satisfaction. European Journal of Business and Management, 6(11), 143-148.

Ali, F., Zhou, Y., Hussain, K., Nair, P. K., \& Ragavan, N. A. (2016). Does higher education service quality effect student satisfaction, image and loyalty?: A study of international students in Malaysian public universities. Quality Assurance in Education, 24(1), 70-94. https://doi.org/10.1108/QAE-02-20140008

Amin, S. (2017). Strategi Peningkatan Kualitas Pelayanan Akademik pada Perguruan Tinggi. Madaniyah, 7(2), 222-236.

Chopra, R., Chawla, M., \& Sharma, T. (2014). Service Quality in Higher Education: A Comparative Study of Management and Education Institutions. NMIMS Management Review, 24(May 2014), 5972.

Cronin, J. J., \& Taylor, S. A. (1992). Measuring Quality: A Reexamination and and Extension. Journal of Marketing, 56(3), 55-68.

Cronin, J. J., \& Taylor, S. A. (1994). SERVPERF versus SERVQUAL: reconciling performance-based and perceptions-minus-expectations measurement of service quality. Journal of Marketing, 58(1), 125-131.

Dean, J. W., \& Bowen, D. E. (1994). Management theory and total quality: improving research and practice through theory development. Academy of Management Review, 19(3), 392-418.

Elmuti, D., Kathawala, Y., \& Manippallil, M. (1996). Are total quality management programmes in higher education worth the effort? International Journal of Quality and Reliability Management, 13(6), 29-44. https://doi.org/10.1108/02656719610124 244

Gaspersz, V. (2001). *Total Quality Management. Penerbit PT Gramedia Pustaka Utama.

Gunarto, M., \& Gaffar, V. (2016). Analisis Persepsi Dan Preferensi Masyarakat Terhadap Reputasi Pemeringkat Perguruan Tinggi. Journal Ilmu Manajemen, 5(2), 129-142.

Khodayari, F., \& Khodayari, B. (2011). 
Service quality in higher education Case study: Measuring service quality of Islamic Azad University, Firoozkooh branch. Interdisciplinary Journal of Research in Business, 1(9), 38-46. https://doi.org/10.1080/14783360802622 805

Mwiya, B., Bwalya, J., Siachinji, B., Sikombe, S., Chanda, H., \& Chawala, M. (2017). Higher Education Quality and Student Satisfaction Nexus: Evidence from Zambia. Creative Education, 08(07), 1044-1068.

https://doi.org/10.4236/ce.2017.87076

Parasuraman, Ananthanarayanan, Zeithaml, V. A., \& Berry, L. L. (1988). Servqual: A multiple-item scale for measuring consumer perc. Journal of Retailing, 64(1), 12.

Parasuraman, Ananthanarayanan, Zeithaml, V. A., \& Berry, L. L. (1994). Reassessment of expectations as a comparison standard in measuring service quality: implications for further research. Journal of Marketing, 58(1), 111-124.

Parasuraman, Anantharanthan, Zeithaml, V. A., \& Berry, L. L. (1985). A conceptual model of service quality and its implications for future research. Journal of Marketing, 49(4), 41-50.

Pariseau, S. E., \& Mcdaniel, J. R. (1997). Assessing service quality in schools of business. International Journal of Quality \& Reliability Management, 14(3), 204-218. https://doi.org/10.1108/02656719710165 455

Quester, P. G., Romaniuk, S., \& Wilkinson, J. W. (2015). A test of four service quality measurement scales: the case of the Australian advertising industry. Proceedings of the 1995 World Marketing Congress, 384-391. Springer.

Rigotti, S., \& Pitt, L. (1992). Servqual as a measuring instrument for service provider gaps in business schools. Management Research News, 15(3), 9-
17. https://doi.org/10.1108/eb028197

Sakthivel, P. B., Rajendran, G., \& Raju, R. (2005). TQM implementation and students' satisfaction of academic performance. TQM Magazine, 17(6), 573-589. https://doi.org/10.1108/09544780510627 660

Sohail, S. M., \& Shaikh, N. M. (2004). Quest for excellence in business education: A study of student impressions of service quality. International Journal of Educational Management, 18(1), 58-65. https://doi.org/10.1108/09513540410512 163

Sultan, P., \& Wong, H. (2010). Performancebased service quality model: An empirical study on Japanese universities. Quality Assurance in Education, 18(2), 126-143. https://doi.org/10.1108/09684881011035 349

Tenner, A. R., \& DeToro, I. J. (1992). Total quality management: Three steps to continuous improvement. AddisonWesley Longman.

Thomas, S. (2011). What Drives Student Loyalty in Universities: An Empirical Model from India. International Business Research, 4(2). https://doi.org/10.5539/ibr.v4n2p183

Yuniarti, Y. (2017). Pengaruh Physical Evidence Terhadap Kepuasan Mahasiswa Program Reguler Mandiri Fakultas Ekonomi dan Bisnis Universitas Jambi. Jurnal Sains Sosio Humaniora, 1(1), 915.

Zeithaml, V. A., \& Bitner, M. J. (2000). Services Marketing. McGraw-Hill Education (India) Pvt Limited. 